Review: Beyond the Acropolis: New Installations of Greek Antiquities in Athenian Museums Author(s): NASSOS PAPALEXANDROU

Review by: NASSOS PAPALEXANDROU

Source: American Journal of Archaeology, Vol. 114, No. 3 (July 2010), pp. 549-556

Published by: Archaeological Institute of America

Stable URL: http://www.jstor.org/stable/25684294

Accessed: 14-05-2015 19:04 UTC

Your use of the JSTOR archive indicates your acceptance of the Terms \& Conditions of Use, available at http://www.jstor.org/page/ info/about/policies/terms.jsp

JSTOR is a not-for-profit service that helps scholars, researchers, and students discover, use, and build upon a wide range of content in a trusted digital archive. We use information technology and tools to increase productivity and facilitate new forms of scholarship. For more information about JSTOR, please contact support@jstor.org. 


\title{
Beyond the Acropolis: \\ New Installations of Greek Antiquities in Athenian Museums
}

\author{
NASSOS PAPALEXANDROU*
}

\begin{abstract}
New Installations of Greek and Cypriot Antiquities in the National Archaeological Museum of Athens, Opened 1 March 2009, curated by Nikos Kaltsas and Elissavet Stasinopoulou (general oversight), Evangelos Vivliodetis and Christina Avronidaki (Greek terracottas, Myrina terracottas), Georgios Kavvadias and Anastasia Gadolou (Vlastos Collection), Elissavet Stasinopoulou and Eleni Zosi (Greek jewelry and silver vessels), Elissavet Stasinopoulou and Christina Avronidaki (glass vessels), Eleni Konstantinidi, Eleni Papazoglou-Manioudaki, Eleni Kourinou, and Despoina Kalesopoulou (Cypriot Collection).
\end{abstract}

\section{Reinstallations of Greek Antiquities in the} N.P. GOUlandris Foundation MusEum OF CYcladic Art, Athens. Ancient Greek Art: A History in Images, Opened 1 August 2009, curated by Nikolas Papadimitriou; ScENES From DAILy Life in ANTiQuity, Opened I November 2008, curated by Nikolas Stampolidis and Yorgos Tassoulas.

Ancient Cypriot Art in the National ArChaeological Museum of Athens, by Vassos Karageorghis. Pp. 151, color figs. 151. A.G. Leventis Foundation and National Archaeological Museum, Athens 2003. €32. ISBN 960-7037-41-3 (cloth).

Scenes from Daily Life in Antiquity, edited by Nikolas Stampolidis and Yorgos Tassoulas. Pp. 28, color figs. 75, DVD 1. Museum of Cycladic Art, Athens 2008. €9 (cloth).

* My heartfelt thanks go to Christina Avronidaki, Evangelos Vivliodetis, Alexandra Christopoulou, Beth Cohen, Giorgos Kavvadias, Marina Plati, Nikolas Papademetriou, Nikolas Stampolidis, Elissavet Stasinopoulou, and Yorgos Tassoulas.

${ }^{1}$ E.g., New Archaeological Museum of Patras (new); Chai-

\section{Leon ANd Melite: Daily Life in Ancient Athens,} by Marina Plati and Eleni Markou. Pp. 28, color figs. 60. Museum of Cycladic Art Educational Programs. Museum of Cycladic Art, Athens 2009. €9. ISBN 978-960-7064-82-0 (cloth).

The epoch-making inauguration of the New Acropolis Museum has overshadowed important museological events in Athens and throughout Greece. Even as the attention of experts and laymen is monopolized by the Acropolis glories in their new home, other museums have worked effectively toward modernizing or expanding their collections. New museums and refurbished regional collections offer alternative models for creative engagements with Greek antiquities. ${ }^{1}$ Pride of place in these fascinating developments, however, should be given to the National Archaeological Museum and the N.P. Goulandris Foundation Museum of Cycladic Art in Athens. The former has inaugurated seven new luminous galleries of impressive artifacts never displayed before. The latter offers a new multisensory installation on ancient daily life alongside a radically new presentation of its classical antiquities.

\section{NATIONAL ARCHAEOLOGICAL MUSEUM OF ATHENS}

The National Archaeological Museum's new galleries are located in the space occupied by the Numismatic Museum of Greece from 1946 to 1998 on the second floor of a wing added in the 1930 s to the east side of the original neoclassical museum building of 1889 by Ernst Ziller. ${ }^{2}$ The variegated nature of the exhibited artifacts and the need to tie their display harmoniously to the rest of the museum determined the style and method of presentation in the new galleries. Their addition underscores the convoluted circumstances of the museum's shaping and its unique trajectory in history. ${ }^{3}$

The inauguration of these new galleries in March 2009 concluded the ambitious project of installation begun after World War II. In recent years, the museum has witnessed the radical refurbishment and reconceptualization of all its galleries. Those dedicated to Roman sculpture, Egyptian antiquities, and the Stathatos Collection made valuable and unique possessions public for the first time. To this day, the

roneia Archaeological Museum (reinstalled).

${ }^{2}$ The Numismatic Museum's current home is the elegant Iliou Melathron, Heinrich Schliemann's neoclassical residence (1878-1889) by Ziller in downtown Athens.

${ }^{3}$ For early history, see Karouzou 1968, xi-xx. 
nature of the museum's displays - an artifact itself worthy of study (if not preservation)-has never veered far from the programmatic intentions of its original curators, Christos Karouzos (1942-1964) and Semni Karouzou (1933-1964). This is essentially a museum of Greek art, mostly conceived in neat categories of art historical and archaeological classification (e.g., sculpture, pottery, bronzes), presented in evolutionary trajectories of regional schools and workshops. The term "archaeological" in the museum's title refers to the time span of pagan antiquity rather than the methods, processes, and contexts of "archaeological" retrieval. The museum thus provides a panorama of Greek antiquity by displaying art as an intellectual creative phenomenon of perennial value, which must be studied in terms of external or internal qualities that sharpen vision and an understanding of the human condition. Karouzos and Karouzou strongly believed in the pedagogical value of this conception of the art museum and, more importantly, in its capacity to improve social life and culture. ${ }^{4}$ The new galleries complement the National Archaeological Museum's narrative in ways hitherto unparalleled in other museums in Greece.

Access to the new galleries is through the gallery of Attic vases of the fourth century B.C.E. First, visitors enter a small gallery with only two cases displaying fine specimens of Hellenistic pottery, most notably Hadra vases, West Slope Ware, Gnathia Ware, and Megarian bowls, which are primarily donations and purchases by collectors. The gallery of Cypriot antiquities is on the left, and, on the right, visitors enter a long sequence of galleries containing Greek terracottas (two rooms), the Vlastos-Serpieris Collection (two rooms), the larger hall of Greek jewelry and silver vessels, and an intimate room of glass vessels.

All the galleries are elegantly simple, directing visitors' attention to their mind-boggling plethora of artifacts. The National Archaeological Museum has always been a repository of materials that were excavated legally, confiscated from clandestine operations, purchased, or donated. Most of the artifacts in these galleries occupy spacious, internally lit cases that hide the walls; additional cases in the middle of the space highlight objects worthy of special attention. The ambient artificial light is generally intense but not overbearing. Numerous graphs, maps, and encyclopedic wall texts supply visitors with basic information. The object labels are generally laconic, but at times they contain treasure troves of information. All texts are given in both modern Greek and English.

Titled "A World in Miniature," the first room of terracottas is a copiously illustrated primer in Greek coroplastic art. Attica, Corinth, East Greece, various Peloponnesian workshops, and Crete are all represented here with numerous characteristic types dating from the ninth to the first centuries B.C.E. A study collection requiring repeated visits, this gallery might well be considered a Boeotian room with materials from other workshops to set off the versatility, color, and ingenuity of this region. Walking into the gallery, visitors

${ }^{4}$ Schefold 1969; Karouzos 1981, 137-39; see also Karouzou (1968, xviii-xix) for her guiding principle in the sculpture installation. On Karouzou, see Nikolaidou and Kokkinidou 1998, 237-44.

${ }^{5} \mathrm{NM}=$ National Archaeological Museum inventory number. are welcomed by an archaic polos goddess of ca. 550 B.C.E. from Tanagra (NM 4009) ${ }^{5}$-a plank with an uncanny gaze. She shares the company of a proud rider, also from Tanagra (NM 4017) and a colorful quadriga (NM 4082). Also in the limelight here are some impressive protomes of gods and goddesses from the sixth and fifth centuries B.C.E., many elegant Tanagra maidens from the fourth to the second centuries B.C.E., and even a child of ca. 300 B.C.E. holding a comic mask (NM 4679). Greek mythical narrative is exemplified by a group of Melian reliefs from the early fifth century B.C.E. Finally, three diachronic thematic units-"Daily life," "The Art of Muses," and "The World of Children"-provide a welcome foil to the regional groupings.

The next gallery contains the delightful Ioannis Misthos Collection of Hellenistic terracottas from Myrina and of terracottas illustrating "Comedy in Ancient Greece" (fig. 1). Humor, gender, and Eros dominate here as nowhere else in Athens. The superb quality and typological variety of the Myrina terracottas bring a vibrant, joyful world to life. Coquettish women embracing, gossiping, cajoling, flirting, and lovemaking share the company of Aphrodite, flying victories, frolicking Erotes, sexy dancing youths, and assorted theatrical characters. Splendidly highlighted in the middle of the room is a terracotta statue of chubby Eros Bound (NM 5080) of ca. 100 B.C.E. Next to it, a virtuosic group of a girl and a weightless Nike playing ephedrismos (piggyback) (NM 5083) teases spectators. The two wall panels give only basic, diagrammatic information. We learn that Misthos donated the collection to the museum in 1884 , shortly after the necropoleis of Myrina had been excavated by French archaeologists. ${ }^{6}$ The breadth of the material, however, generates questions: Who was Misthos? How did he obtain so many examples? How did they escape the French mission's excavations?

The following two galleries pay tribute to the astute entrepreneur Gregory Vlastos' (1874-1936) collecting habit, its social milieu, and his scholarly attitude. ${ }^{7}$ His unique collection is represented here for the first time by 452 objects (out of 760). Numerous Tarantine antiquities-unusual in a Greek museum-acknowledge the artistic output of South Italian Hellenism and Vlastos' own expertise in the coinage of Taras. The display rewards visiting scholars in unanticipated ways. A fragment of a terracotta relief plaque from Crete with a male figure of the seventh century B.C.E. (case 4, no. 7, B $\Sigma 667$ ) is strikingly close to a similar, but much better preserved, plaque in the Greek terracottas gallery nearby (case 2, no. 14, NM 10180). And a similar plaque is displayed on the second floor of the Cycladic Museum of Art. ${ }^{8}$ The fortuitous coexistence of related examples in two Athenian museums generates questions. Do these objects originally come from the same source? Were they made from the same mold? What networks of circulation account for their surfacing in three different private collections? How typical is this? Displays like these show that museums and collectors alike managed to reverse the mess inflicted by clandestine excavations.

\footnotetext{
${ }^{6}$ Pottier and Reinach 1887.

${ }^{7}$ Vlastos' collection has been in the National Museum since 1988. On Vlastos, see Maragou 2001, 14 n. 11.

${ }^{8}$ Maragou 2001, 26, fig. 28.
} 


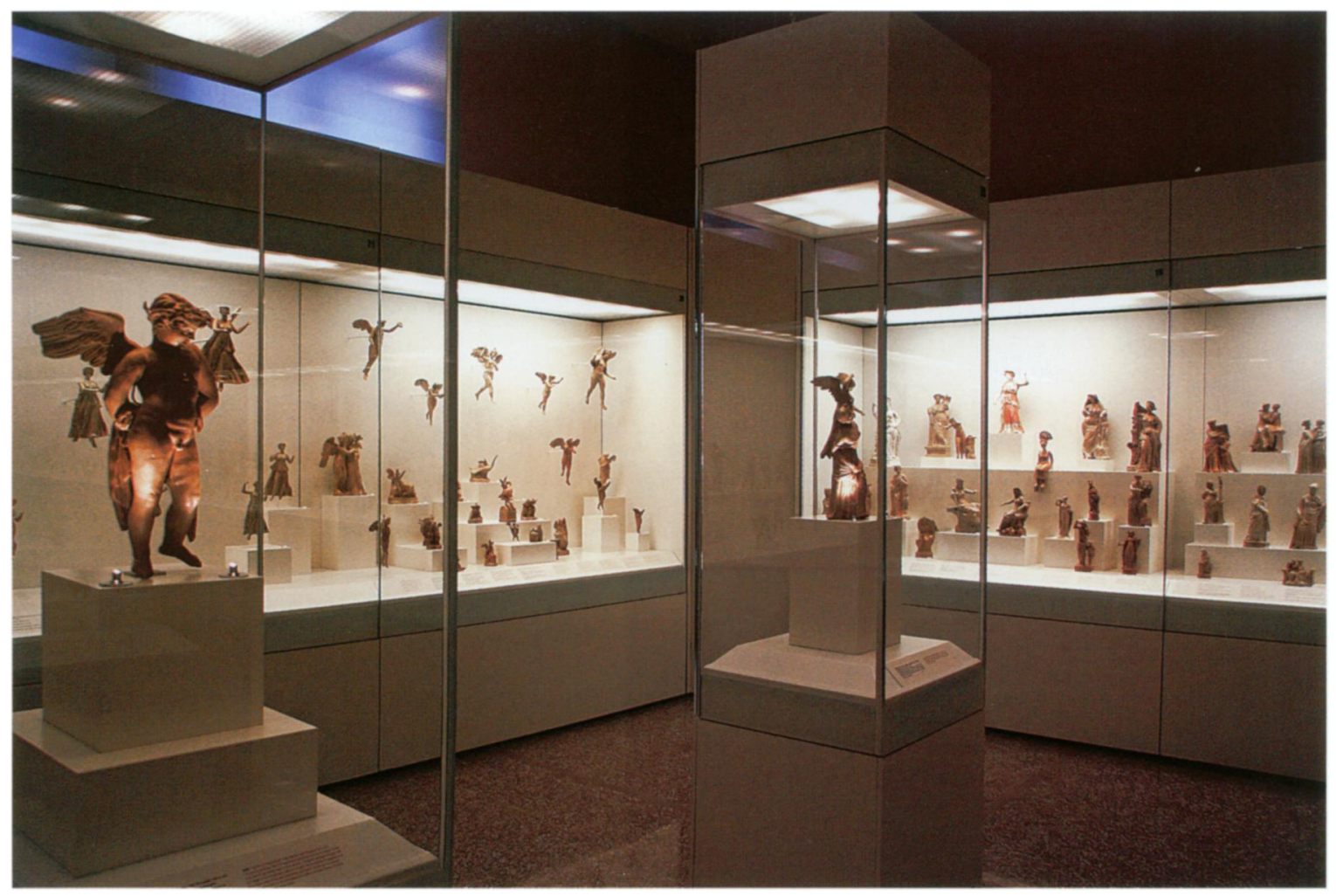

Fig. 1. Installation view of the gallery containing the Ioannis Misthos Collection of Hellenistic terracottas from Myrina and of terracottas illustrating ancient Greek comedy (courtesy National Archaeological Museum of Athens; (C) Hellenic Ministry of Culture-Archaeological Receipts Fund).

Salvaging clandestinely excavated antiquities was, after all, one of the main objectives of many collectors, as is made apparent by the prominently displayed documents, correspondence, and photographs in this installation, which open a fascinating portal onto Vlastos' serious preoccupation with antiquities. A letter of 25 May 1935 signed by Vlastos announces the creation of the Society of Friends of the Museum, "to save for Greece the priceless treasures of its ancient civilization which all too often are secretly exported from the country." This exhibition also emphasizes that under his leadership, the society purchased numerous ancient objects. Finally, at a computer station, visitors can leaf through a digital version of Vlastos' extensive notes and drawings for a CVA fascicle of his collection that never materialized.

The hall of gold jewelry and silver vessels is a veritable treasury (fig. 2). In the introductory case, well-coordinated texts, graphs, and pieces of jewelry illustrate the goldsmith's craft. The rest of the exhibition conjures up a diachronic survey of jewelry from the ninth century B.C.E. to the fifth century C.E. ${ }^{9}$ The method of presentation focuses on impressive reconstituted assemblages of jewelry found in controlled excavations from the middle of the 19 th century onward. These assemblages are the fruit of a painstaking process of retrieval within the museum, including identification, conservation, and even authentication in cases of artifacts unearthed and circulated illegally. Here, sleek black cases contain jewelry often found in the same burial with luxurious silver vessels.

The glittering presentation celebrates Greek goldsmiths' daring ventures in miniaturization; a tiny gold griffin of the fifth century B.C.E. (NM 7257) from the Acropolis, for example, is a masterpiece in filigree. This installation also illustrates changes in style, experiments in combinations of materials, and the popularity of certain themes. For example, a gold earring preserving pearls and a kithara-playing Eros (NM Xp 15113) of ca. 100 B.C.E. comes from the first underwater excavation of the Antikythera shipwreck in 1901. Next to it is a more recent find from the same context-a pair of earrings with Erotes holding folding mirrors (NM X $\rho$ 1579). There are numerous pieces of less-substantial jewelry from the third to the first centuries B.C.E., which functioned only as funeral costume. Other displays introduce us to individuals such as Philotera, daughter of Amymone, who was buried in the third century C.E. outside Athens' Dipylon Gate. Her marble sarcophagus was discovered in 1874 . We know her name because her elaborate openwork gold bracelet spells it out in elegant letters (NM X $\rho$ 71). She was buried bedecked

\footnotetext{
${ }^{9}$ Except for the exquisite figural ivories of a funeral couch from the Tomb of the Palmettes at Lefkadia, Macedonia.
} 


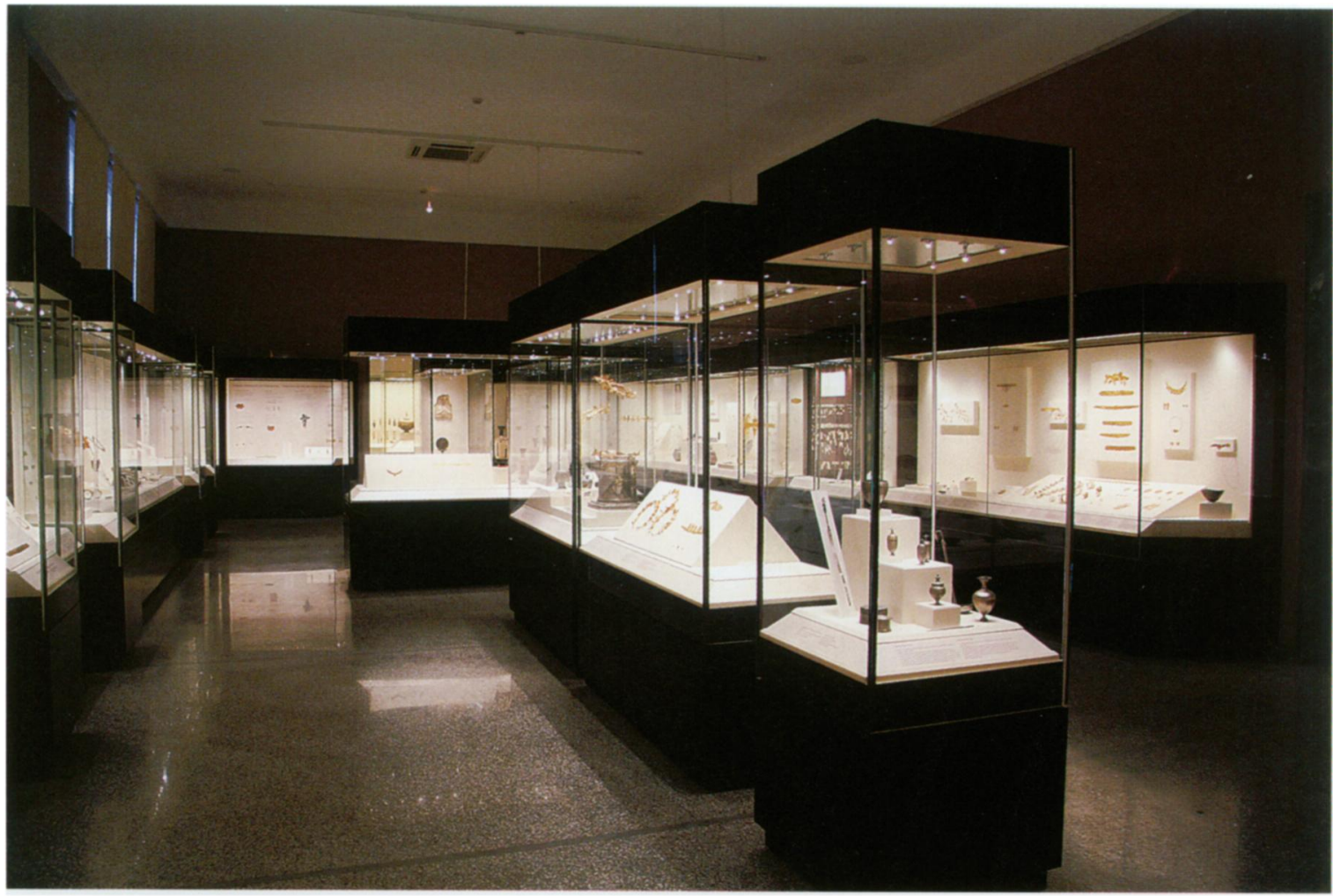

Fig. 2. Installation view of the gallery of Greek jewelry and silver vessels (courtesy National Archaeological Museum of Athens; (C) Hellenic Ministry of Culture-Archaeological Receipts Fund).

in a pair of gold polyhedral earrings (NM X $\rho 78$ ), a bronze coin sheathed in gold (NM X $\rho 200$ ), and two gold armbands studded with engraved sealstones (NM X $\rho$ 4-5).

The amplitude of the National Archaeological Museum's installations, their documentary force, and their beauty are also manifest in the "Glass Vessels" gallery. While the wall texts and illustrations of glass manufacture are detailed and informative, visitors appreciate most the stupendous quality and state of preservation of the vessels on display. All the major glass-making techniques are exemplified here with exquisite specimens, many of them from excavated contexts. Viewers marvel at a finely textured bluish-green bowl (NM 23712) discovered intact in the Antikythera shipwreck or two transparent imitation agate vases from a second-century B.C.E. grave at Palaikastro, Thessaly (NM 14261, NM 14262a). A transparent cast bowl from Siphnos with engraved Erotes merrily mounted on sea monsters (NM 16275) of ca. 100 B.C.E. is another delight of this gallery's display.

The generous sponsorship of the A.G. Leventis Foundation is evident in the sun-drenched gallery of Cypriot antiquities (fig. 3). ${ }^{10}$ The presentation here is commensurate with that in other galleries, but the wall texts are more richly illustrated and are supplemented by two interactive computer screens. A magnificent photograph mural of the famous as-

${ }^{10}$ It includes 180 artifacts out of 850 . For history, see Karageorghis 2003, 12-14. semblage of terracotta votives at the sanctuary at Hagia Irini, now in the Medelhavsmuseet, Stockholm, embellishes the gallery's north wall. ${ }^{11}$ This provides an appropriate backdrop for seven glass cases containing characteristic examples of Cypriot coroplastic art, which range in date from ca. 1900 to ca. 400 B.C.E. and include nude female figures, either holding their breasts or clasping hands, and a chorus of tambourine players. On the other side of the gallery, first-rate vases illustrate Cypriot pottery in a colorful trajectory that takes into account the role of Cyprus in Mediterranean commerce, especially copper trade. Central cases offer graceful examples of Cypriot limestone sculpture from the sixth century B.C.E. to ca. 100 C.E. Smiling worshipers, korai, kourotrophoi (mothers holding infants), and temple boys can be appreciated vis-à-vis sculpture from Greece elsewhere in the museum. Two standing figures with exaggerated, tall bodies demonstrate the charming otherness of Cypriot visual culture.

\section{N.P. GOULANDRIS FOUNDATION MUSEUM OF CYCLADIC ART}

Since its opening in 1986, the Museum of Cycladic Art has been at the forefront of interweaving aesthetically flawless exhibitions and didactic programs for diverse audiences. Housed in a 1985 modernist white marble and glass building 


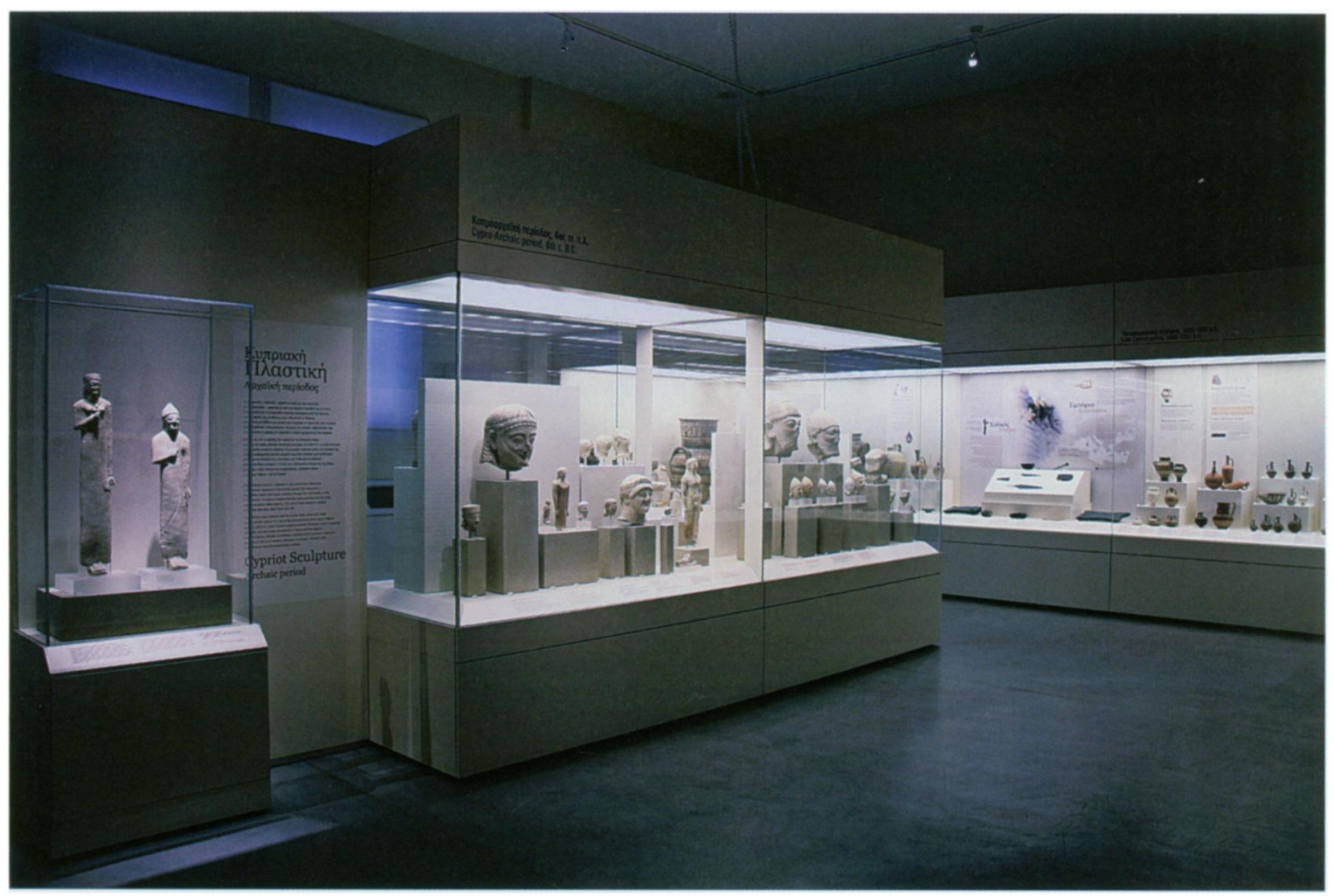

Fig. 3. Installation view of the A.G. Leventis Foundation gallery of Cypriot antiquities (courtesy National Archaeological Museum of Athens; (C) Hellenic Ministry of Culture-Archaeological Receipts Fund).

in Athens' chic Kolonaki district, the museum is famous for its collection of Bronze Age Cycladic sculpture, the original core of which was salvaged from illegal export by the spirited collector Dolly N. Goulandris (1921-2008) in the 1960s and 1970 s. $^{12}$ The exemplary display of the famous figurines from the 1980s still holds up well.

Equally important is the museum's diverse collection of classical antiquities, ${ }^{13}$ which has grown considerably, since its shaping in the 1960s, from donations, loans, and purchases by the N.P. Goulandris Foundation. ${ }^{14}$ Through the acquisition of various important collections, including those of Lambros Eutaxias and Karolos Politis, the museum has added to its DNA important strands of the socially and culturally complex history of modern Greek collecting. ${ }^{15}$ Most of the collection consists of pottery, which ranges in date from Mycenaean to Hellenistic times, though Attic blackfigure and red-figure vases of the sixth and fifth centuries B.C.E. predominate. ${ }^{16}$

Both of the Museum of Cycladic Art's newly reinstalled floors cater to wide audiences. A primary motivating force behind their conception and organization is the traditional

\footnotetext{
${ }^{12}$ Doumas 1968; Doumas and Maragou 1978. For recent acquisitions, see Maragou 2001, 18-32.

${ }^{13}$ Doumas and Maragou 1978, 147-334; Maragou 1996.

${ }^{14}$ Maragou 1996, 18; 2001, 18-32.
}

emphasis of this museum on didactic content and educational programs. Since the 1980s, the Educational Department has implemented a series of sophisticated programs that target students 10-13 years of age. This involves the use of special educators and a prescribed agenda of action, during which the students are led to discover by themselves qualities, functions, and relations of objects to people and places. This experience sharpens their senses and naturalizes young learners to the museum space. ${ }^{17}$

The new installations, moreover, dojustice to the breadth and quality of the museum's collection. In addition to didactic content, major determinants in their design have been the nature of available space and the museum's programmatic emphasis on didactic content. The museum's L-shaped floor plans facilitate intimate settings in which displayed objects are in constant dialogue with one another.

Ancient Greek Art: A History in Images, the new installation on the second floor, is woven around the idea of a pictorial journey through time and space, with major thematic stops and highlights. Its colorful and playful physical layout reminds me of the Mediterranean, with its large islands, straits,

\footnotetext{
${ }^{15}$ Maragou 2001, 18-32. For the Politis Collection, see Papadopoulou-Kanellopoulou 1989.

${ }^{16}$ Maragou 1996; Papadopoulou-Kanellopoulou 1989.

${ }^{17}$ On method, see Plati 2007; Plati and Markou 2009.
} 
promontories, hidden coves, and "harbors you're seeing for the first time." 18 One can navigate around the shores, but no trajectory is mandatory. The "islands"-here, cases in the middle of the gallery-are obliquely positioned, enlivening the space and facilitating juxtapositions and comparisons: they invite deviation, disrupting or redirecting the flow and interaction of visitors with the images. The installation is articulated in clearly distinct units and subunits with the spatial transitions bounded by unobtrusive glass dividers, whose visuals, such as a satyr's head for "Archaic Greece," discretely beckon the visitor.

Alighting on one of the islands, I was pleasantly surprised to encounter a wonderfully preserved Cretan shield of the early eighth century B.C.E. hammered in bronze and embossed with the representation of a sensuous Potnia amid beasts. ${ }^{19}$ Like the island of Crete, this shield occupies a strategic link between the austerity of Attic Late Geometric vases from the eighth century B.C.E. and the new horizons of the Archaic period in the seventh and sixth centuries. Invitingly labeled "The Birth of the Figure," the Geometric "island" itself introduces the first images in Athenian tradition, notably centaurs, horses, chariots, and the lions that roar from the bottom of a small cup. ${ }^{20}$

Around these islands, the walls are lined with embedded cases in soothing colors, such as pale green or gray, that never compete with the exhibited artifacts. Each individually lit object is easily visible and has a unique story to tell. A case in one nook is devoted to citizen hoplites of the Greek city-state (fig. 4). Here, three Corinthian helmets are set on swordlike props against an earthy red background that evokes death and the somber mood of war. The wide frame of this case is printed with the phalanx from the proto-Corinthian Chigi vase, a visual prop that contextualizes the helmets. In adjacent cases, the escapist merriment of Dionysiac dancers on a black-figure lekythos and the prancing komasts of an unforgettable Corinthian krater inspire contrasts and tension. ${ }^{21}$ In an "island cove" exploring "Daemons and Monsters," the visual prop of the ketos on a famous Caeretan hydria invites scrutiny of fabulous creatures from Boeotia in the case above it: sphinxes on a black-figure lekanis, sirens on an aryballos, a terracotta centaur with heavy genitals, and a terracotta ithyphallic Silenos with a pet monkey on his shoulder. ${ }^{22}$

The labels are succinct, but there is plenty of background information on text panels, both inside and outside the cases. Prominent thematic labels of units and cases signal the core ideas that motivate the installation so that visitors always know exactly what they are looking at. For example, "Nature" is the overarching framework for exploring the cases labeled "Art and Minoan Religion" and "Trade and Daily Life" that deal with Bronze Age phenomena. In the classical section, "Balance" is the guiding theme for studying aspects of ancient life and its images, such as the "Economic Basis of Democracy" and "Theater and Dionysiac Cult."

\footnotetext{
${ }^{18}$ For Cavafy's Ithaca, see Savidis 1975, 35.

${ }^{19}$ On loan from the Rethymnon Museum, inv. no. M 2803.

${ }^{20}$ Papadopoulou-Kanellopoulou 1989, 43-50, nos. 19, 235 . An oinochoe, a lidded pyxis, and a pitcher, in this case, come from the Chatzidimos Collection (Maragou 2001, 25-6).

${ }^{21}$ For the lekythos, see Maragou 1996, 83, no. 120. For the krater, see Maragou 2001, 46.
}

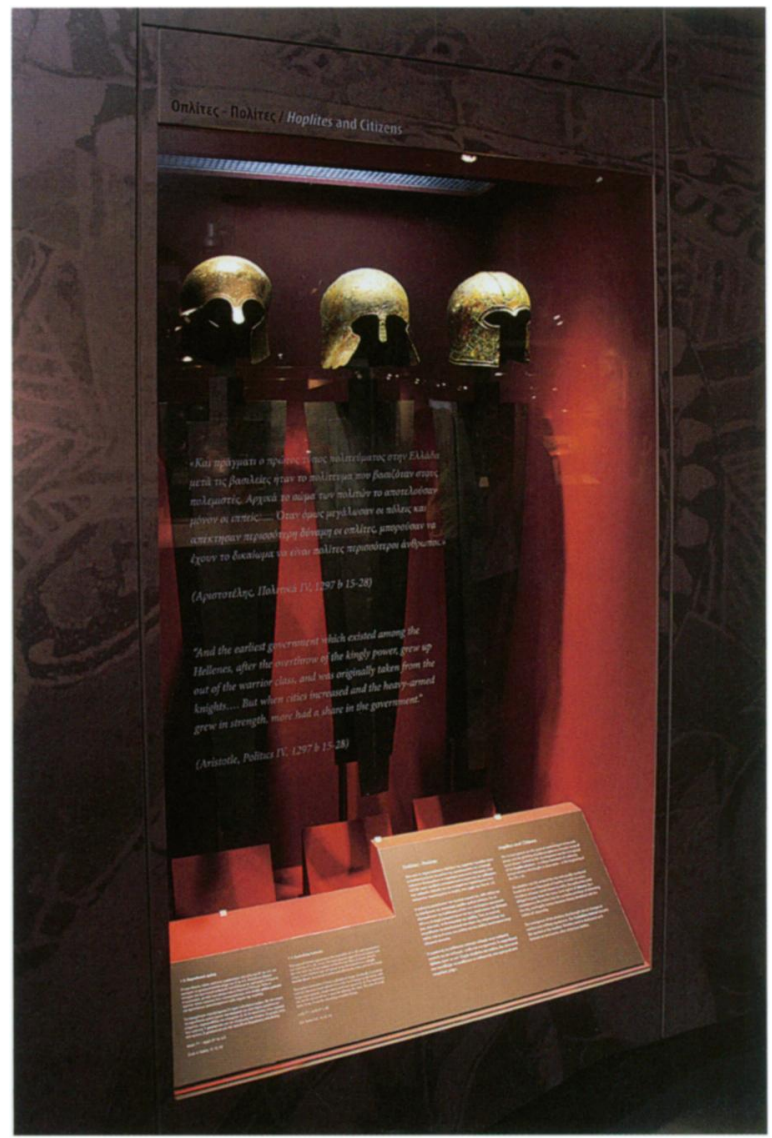

Fig. 4. View of the showcase "Hoplites and Citizens" in the second-floor reinstallation Ancient Greek Art: A History in Images (C. Akriviadis; $\odot$ N.P. Goulandris Foundation-Museum of Cycladic Art).

At a crucial juncture, a glass case projects from the wall like a promontory to introduce the theme of "Expression" in Hellenistic culture. It showcases a miniscule female head of a terracotta figurine, whose charming smile is as radiant as that of the much larger marble statue of a boy in the Hellenistic octagonal cove nearby. ${ }^{23}$ In the same case as the figurine, an artfully crafted bronze askos of the second century B.C.E. has a handle animated by minute animal heads. ${ }^{24}$ The calculated symbiosis of the terracotta head and the bronze askos is a riff on the constant preoccupation of Hellenistic art with dramatic juxtaposition and surprise.

The culmination of the installation of ancient Greek art is an attractive interactive section titled "How Were They Made? Technologies of Fire." This unit takes the form of a

${ }^{22}$ Visual prop: Niarchos Collection, inv. no. A 061 (hydria attributed to the Eagle Painter, ca. 530-520 B.C.E.); lekanis: Maragou 1996, 92, no. 126; centaur: Papadopoulou-Kanellopoulou 1989, 107, no. 55; Silenos: Papadopoulou-Kanellopoulou 1989, 119, no. 69 .

${ }^{23}$ Maragou 1996, 181, no. 288.

${ }^{24}$ Maragou 1996, 172, no. 271. 
stepped wall articulated by five stations that treat prominent categories of objects on display in the gallery: clay vases, clay figurines, bronze objects, gold jewelry, and glass vases. The station for each class of object contains text and graphics on the wall, a digital screen for video, rotating panels, and drawers full of surprises. The stations offer a rich and playful menu of options for discovering step-by-step the nuts and bolts of arts and crafts in antiquity. Here, visitors, especially children, are free to give vent to the tactile urge that usually is repressed in a museum setting. This engaging tool prompts reflection on the role of all artworks in a society's economy and on the messiness of life-the sweat, dirt, and toil of free persons and slaves alike.

An altogether different set of challenges and rewards, both cognitive and emotional, await the visitor to Scenes from Daily Life in Antiquity on the fourth floor (fig. 5). This new installation actualizes a synchronic view of the everyday. Here, antiquity has been treated with a sensitivity informed by a studied avoidance of simplification, qualities also evident in the slim but richly illustrated educational guide for this installation. ${ }^{25}$

Upon entering, the visitor faces Dionysos in the title panel, an inviting enlargement of the famous tondo inside the Munich cup by Exekias with the god reclining majestically on a ship whose mast sprouts vines. This visual epigraph encapsulates the overarching theme-a journey in which the vibrancy of life is never far away from death and the beyond. Two introductory displays, "Gods and Heroes" and "On the Wings of Eros," lead to six "stations" that explore aspects of female gender ("Toiletry and Wedding," "Women's Activities"), the construction of masculinity ("Athletics"), all-male social life ("Symposium"), and civic life ("Warfare" and "Athenian Agora"). The organizing thread here is a fictional character named Leon, a handsome Athenian citizen, whose biography typifies the roles, constraints, obligations, and joys of a member of the middle class living in the fifth century B.C.E.

The fourth-floor display is a mixed-media installation in hues of black and red. At its core is a panoramic assemblage of 175 ancient artifacts shown against life-sized photographic views of Leon and his family, friends, and peers. These actors perform in front of stylized backdrops of constant elements in their lives. This clever contraption works both ways: the two-dimensional images of the main protagonists blend with the three-dimensional artifacts and vice versa. In "Women's Activities" for example, we see Leon's mother feeding baby Leon with a real black-glazed terracotta feeder against a photographic backdrop of teased wool ready to be spun by her and other female members of the household. Toys in the same display, such as knucklebones and dolls with moving limbs, illustrate daily activities of children. A modern replica of a loomweight and real spindlewhorls suggest the main domestic preoccupation of women. In the symposium case, a nude slave boy pours wine from a bronze jug into a bronze kylix in front of a fine red-figure krater attributed to the Göttingen Painter of ca. 500-490 B.C.E., suggesting infi-

\footnotetext{
${ }^{25}$ Stampolidis and Tassoulas 2008.

${ }^{26}$ Jug: Maragou 1996, 167, no. 263; kylix: Stampolidis and Tassoulas 2008, s.v. "Symposium" (Politis Collection, inv. no. $35)$; krater: Stampolidis and Tassoulas 2008, s.v. "Symposium."
}

nite comparisons of scales, shapes, functions, and images. ${ }^{26}$ The objects are real, and it is easy for viewers to play along in bringing the boy to life as well. This scenario invites us to meet and empathize with Leon and his world. Inversely, it brings Leon into our world, inviting contrasts and unavoidable, sometimes even painful, comparisons.

This dialogic process is also facilitated by comic-strip friezes and object labels that provide visual and verbal commentary in Greek and English on the functions of exhibited objects and the aspects of life that made them necessary. With humor and subtlety, they visualize gods and people such as athletes, slaves, musicians, politicians, and prostitutes in everyday situations. In a scene with a lebes gamikos (a cauldron-shaped wedding vase), newlyweds are ready to engage in sex. Elsewhere, visitors see symposiasts-no sex between men or between men and boys is shown-joyfully playing kottabos by flirtatiously aiming the dregs of wine in their cups at their peers. In the Athenian Agora case, we see and hear the resounding banter between sellers and buyers. These tasteful strips spur viewers to engage fully their creative imaginations. Younger visitors will enjoy them the most.

Appropriately used special effects encourage us to suspend contemporary subjectivities. Ceiling gobo lights project images from vases on the gallery's dark floor-for example, one is a symposiast and an aulos player in front of the symposium station. Past the six stations about Leon, a small theater shows in continuous projection a short video that offers evocative glimpses into Leon's life from his birth to his demise in battle. Its musical score, punctuated by tones of the syrinx and the aulos, is redolent of the soundscape of Leon's distant world.

Leon's death is heart wrenching but necessary, considering that antiquity has always been idealized beyond measure in Greece. And Greek museums have provided cold academic constructs of the past that have never engaged the public. ${ }^{27}$ This installation consciously goes against that grain. The itinerary climaxes in a hidden dark cove that explores "Taking Care of the Dead." Here, a shorter video picks up the action after Leon's death. Visitors participate in his funeral, which is shot in dark tones that evoke the tragedy of death. Visitors watch the prothesis with women lamenting, the ekphora, the cremation of his body, and the burial of his ashes in a bronze hydria. A funeral stele on a low stepped base is visited by the female relatives who bring flowers and offerings, perform libations, and lovingly anoint it with oil. The final scene zooms in on the stele, then lights go down, and the still dissolves into its materialized replica inside the museum. Leon's bronze urn is visible below in a simulated grave shown in cross-section. Leon's fictional monument turns into a still, silent life, allowing us to reflect on the eight humble lekythoi on the steps. ${ }^{28}$ In this context, these offerings become meaningful funerary gestures. Context here emerges not only as a physical and spatial category but also as an essential dimension of behavior. Leon was treated with propriety and all due respect. These reenactments urge visitors to rethink Leon's life vis-à-vis the artifacts in this instal-

\footnotetext{
${ }^{27}$ Damaskos and Plantzos 2008.

${ }^{28}$ E.g., a white-ground lekythos of ca. $460-450$ B.C.E., attributed to the Tymbos Painter.
} 


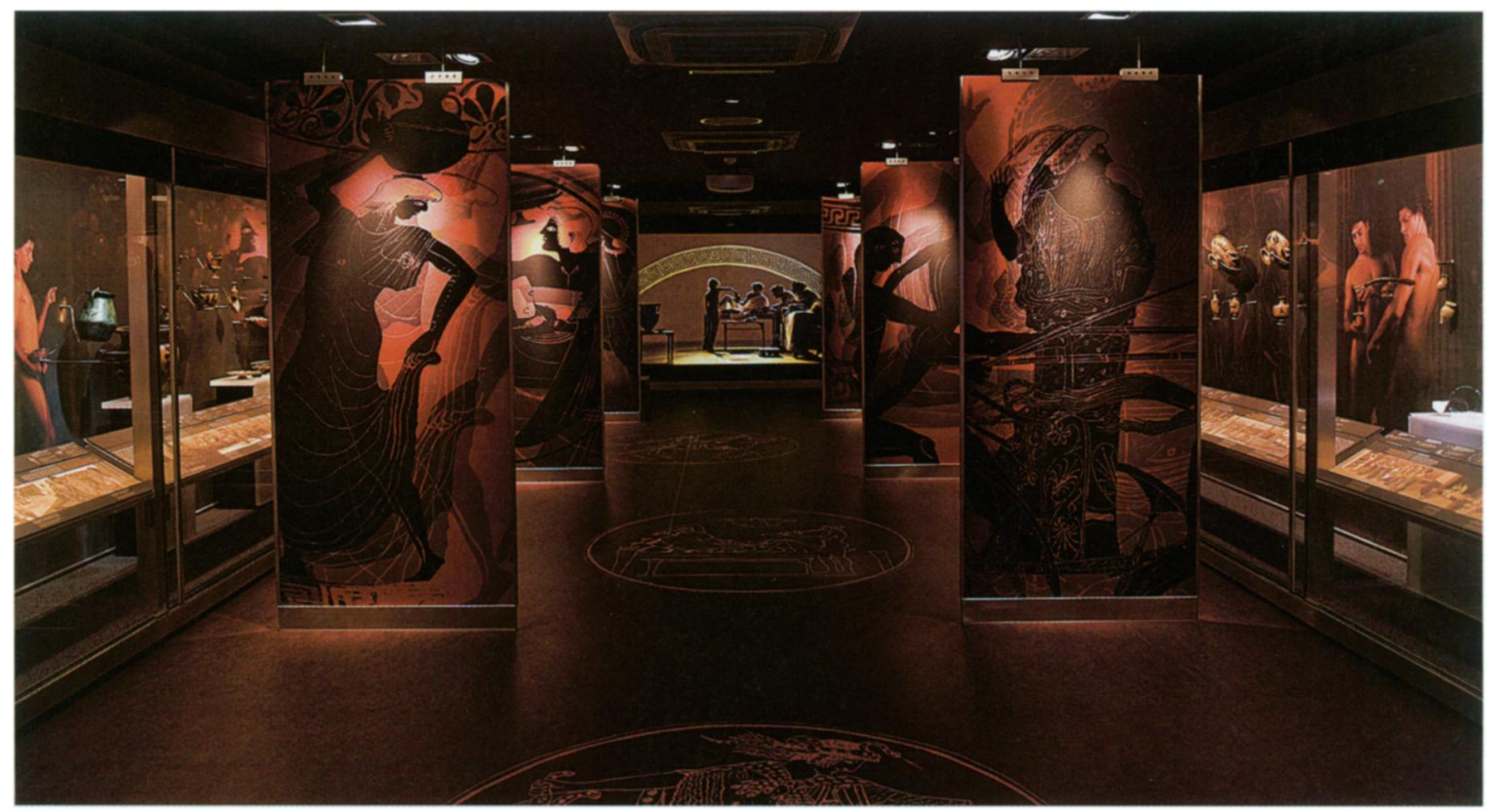

Fig. 5. View of the fourth-floor reinstallation Scenes from Daily Life in Antiquity (G. Fafalis; @ N.P. Goulandris FoundationMuseum of Cycladic Art).

lation. His monument prompts reflection on ancient and contemporary spectacles of commemoration, especially the extent to which museums can relate their artificial constructs with contemporary realities.

The world of Athenian museums has been embellished by these innovative installations. They offer multiple views of the Greek past even as they exemplify a polyphony that is possible only in Athens. Both museums provide clear pathways for appreciating phenomena far distant from the splendor of the Acropolis but no less important. Both are major protagonists in the epic effort to salvage and curate a messy but infinitely interesting past.

\section{DEPARTMENT OF ART AND ART HISTORY}

THE UNIVERSITY OF TEXAS AT AUSTIN

AUSTIN, TEXAS 78712 -0337

PAPALEX@MAIL.UTEXAS.EDU

\section{Works Cited}

Damaskos, D., and D. Plantzos eds. 2008. A Singular Antiquity: Archaeology and the Hellenic Identity in the Twentieth Century. Athens: Benaki Museum.

Doumas, C. 1968. The N.P. Goulandris Collection of Early Cycladic Art. Athens: J. Makris.

Doumas, C., and L. Maragou, eds. 1978. Ancient Greek Art: The N.P. Goulandris Collection. Athens: Benaki Museum.

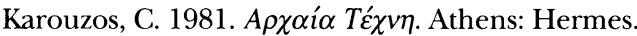

Karouzou, S. 1968. National Archaeological Museum: Collection of Sculpture. Translated by H. Wace. Athens: General Direction of Antiquities and Restoration.

Nikolaidou, M., and D. Kokkinidou. 1998. “Greek Women in Archaeology: An Untold Story." In Excavating Women: A History of Women in European Archaeology, edited by M. DíazAndreu and M. Sørensen, 229-58. London: Routledge.

Maragou, L. 1996. Ancient Greek Art: N.P. Goulandris Collection. 2nd ed. Athens: Museum of Cycladic Art.

- 2001. Museum of Cycladic Art: Activities Report 1991-1999. Athens: Museum of Cycladic Art.

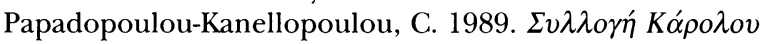
Пo $\lambda i$ in. Athens: Archaeological Receipts Fund.

Plati, M. 2007. Once Upon a Time a Potter-Teacher's Pack. Athens: Museum of Cycladic Art.

Pottier, E., and S. Reinach. 1887. La nécropole de Myrina. Paris: E. Torin.

Savidis, G., ed. 1975. C.P. Cavafy: Collected Poems. Translated by E. Keeley and P. Sherrard. Princeton: Princeton University Press.

Schefold, K. 1969. “Christos Karousos' Aesthetik.” ArchDelt 24(1):230-39.

Winbladh, M.L. 2003. "The Open-Air Sanctuary at Ayia Irini." In The Cyprus Collections in the Medelhavsmuseet, edited by V. Karageorghis, 151-203. Nicosia: A.G. Leventis Foundation. 